\title{
THE TRENDS OF THE LAKE TOURISM AND RESULTS OF BALATON RESEARCH
}

\author{
Remenyik Bulcsú ${ }^{1}$, Molnár Csilla² \\ ${ }^{1}$ associate professor, ${ }^{2}$ associate professor \\ ${ }^{1}$ BGE-KVIK Institute of Tourism, ${ }^{2}$ GTK Szent István University \\ E-mail: ${ }^{1}$ Remenyik.Bulcsu@uni-bge.hu, ${ }^{2}$ Molnar.Csilla@gtk.szie.hu
}

\begin{abstract}
Water is a natural resource that is the foundation of the most successful tourist destinations around the world (Mill-Morrison, 1992). Ponds, by virtue of their generation and development, have the characteristics that determine their utilization in tourism (Cooper etal., 2008). The spectacle and mood of the large, calm water mass, the wildlife and the diverse natural and cultural values of the background towns attract visitors to a multitude of visitors (Rátz Michalkó 2007). This product of tourism may, depending on the destination concerned and the directions of development belong to the subject of mass and alternative tourism (Remenyik Tóth - Molnár, 2013). The present study, which compares and contrasts the tourism and visitorbased economic development at Balaton lake in Hungary aim to describe how roles have changed and opportunities have presented themselves in the lake tourism sector. That in the interest of the forming of the qualitative tourism the importance of the government onto the development of the lake tourism is by way bigger, his support on the increase of the star grade of the accommodations, the development aquatic and road infrastructure and the construction of the topic park of Lake Balaton. The inland ones are in a great majority opposite the foreign country guests considering the guest construction in the lake tourism; with the support of the tourism products it is possible to develop directly the Hungarian small- and medium-size enterprises.
\end{abstract}

Keywords: lake tourism, destination management, tourism development

JEL: R1, O20

LCC: GV182-182.5

\section{Introduction}

In the western part of Central Europe (Germany, Switzerland, Austria and Slovenia), lake tourism has already become a leading tourism product since the $1970 \mathrm{~s}$. Winter mass tourism in the 1960s encouraged the people to live in an active way of life, while lake tourism became a leading product in the summer (Marton, 2013). Lake tourism with its 4S (Sailing, Swimming, summer, and Surfing) could be approached by nearly every age group (Remenyik - Tóth Molnár 2013). Lake tourism was developing best on the bigger lakes such as the Balaton, Tisza and Velence Lake, they became the most popular spots of Hungarian lake tourism.

Regional tourism builds connection with active tourism, human ecology does the same with ecotourism and settlement ecology is in contact with cultural and heritage tourism.

Instead of the mass water tourism with recreational activities such as sunbathing, swimming, playing in the coasts etc. water tourism can be classified in the following categories:

Hand-driven means of transport, primarily canoes and kayaks belong to the category of classic water tourism. Their direction is towards the downstream of the water (descending, flowing). 
Trips lasting for a couple of days and several harbour or stops are there during these tours. These trips can be organized (with a tour leader) and unorganized (individual) as well.

Fishing tourism, as a narrow segment of tourism can play a prominent role in rural development. There are 3 forms of fishing tourism. Participants can fish from the shore, from a rowing boat and from a motor boat. As local knowledge is essential for successful fishing, most of the fishermen insist on their own, known places; so it might be one of the reasons why fishing tourism can be described similar to cycling tourism during which they go on a so-called "lake tour" starting from and returning to a harbour. There is a way to provide visitors with the opportunity to go fishing with local fisherman and share in the culture, tradition and lifestyle of locals. Activities can be conducted all year round (so it can reduce seasonality), day or night, depending on the fishing method and weather conditions. Widening the tourist supply is another advantage and can result increased staying time and incomes.

Ecotourism which is related to water tourism means only few hour long, short boat trips. The bare necessities are just easily accessible ports with more sophisticated harbour facilities, and appropriate amount of boats for the reception of larger groups too. It is also a requirement of the area to provide a tour guide who knows the fauna and the flora of the area well.

Motor boat tourism has two versions: sport shipping and shipping tours. Sport shipping includes water skiing and jet-ski. These are usually linked to a smaller area, usually to storage for boats or ships, or to a port area where they let boats and ships flow on the water. Here we have to mention the possibilities of excursion, boat cruises and recreational activities which are even less exploited in Hungary.

\section{Material and methodology}

The theoretical background of our research was given by the Hungarian and international literature dealing with the tourism system the tourism of lakes, the tourism region of Lake Balaton, and sustainability.

Most of the data used in our analyses comes from the database of the Central Statistical Office $(\mathrm{KSH})$.

The analyses of the lakes, similarly to other surveys, can run into difficulties. The reason is that it is utterly difficult to match geographical borders with administrative boundaries. Therefore, in order to dissolve this problem, we decided to use spatial informatics software (ArcView 9.3.1.) to define settlements whose administrative area includes even a 1 square kilometre area that belongs to the lake itself.

In our research the Hoover-index has been applied. It expresses on a $0-100 \%$ scale what percentage of one of the examined indicators (in this case the income from which income tax is calculated) should be regrouped among the settlements of certain sections so that its distribution could punctually equal with the distribution of the other indicator (in this case population) among the settlements. Since settlement groups of different sizes were examined we tried to measure the distribution changes per unit areas for the sake of comparability.

To get known the opinion of visitors and local residents, we used the results of questionnaire research made by the Academy of Tourism of the Budapest Business School University of Applied Sciences. It took place at Lake Balaton between 2nd of July and the 12th of July 2015. The aim of this research is to examine the awareness of the most visited area in domestic tourism 
and to observe the purpose, motivation, duration of stay concerning tourists of certain target groups (young, middle and elderly target groups). The survey consisted of 20 simple and multiple choice questions. According to the research results, the conclusions we can draw are related to the whole domestic tourism of Hungary. The analysis covers those 51 settlements, which were qualified as coastal and offshore by the first and the second supplements of the Hungarian law of 'Balaton Kiemelt Üdülökörzet Területrendezési Tervének elfogadásáról és a Balatoni Területrendezési Szabályzat megállapitásáról szóló 2000. évi CXII. törvény’, so it does not deal with all of the settlements in the special recreational area. The focuspoints of the research were Siófok, Balatonfüred, Révfülöp, Keszthely and Fonyód. More than 6000 surveys were collected. Foreign tourists were interviewed in English and German.

\section{The position of the Lake Balaton in Hungary's tourism}

The objective of this paper is to present the changes in the tourism roles of lake tourism and their development possibilities. There were a number of objectives set in connection with our research. On the one hand we intended to examine whether lake tourism was in a favourable or unfavourable situation in Hungary and also to observe the similarities and differences among lake-side settlements (Dávid-Tóth-Kelemen-Kincses, 2007). On the other hand it was our task to compare lakes and measure them against national averages. Furthermore, we also wanted to find out whether these lake-side settlements were totally different or whether they showed some similarities.

Development of Lake Balaton started is 1963 when the political opinion of the tourism industry changed. The poor economic situation and successful development of the socialist countries (mainly Romania and Bulgaria) have encouraged the head of state to make changes. It has become an "official act" that the principle of tourism should be the principle of a western entry traffic, and thus the increase in foreign exchange earnings (Rehák, 2011). In 1964 the foreign exchange and customs regulations were simplified, the visa issuing procedure was accelerated, visa free travel was introduced with a number of countries and the foreign exchange supply of travellers was also improved. The new economic mechanism starting in 1968 also considered the development of tourism as of highest priority thus lake tourism together with holiday tourism became a leading tourism product in Hungary (Remenyik-Tóth-Molnár, 2013). In the two decades from 1970s, Lake Balaton has become a major destination not only for Hungarians, but foreign visitors (mainly Germans). By the mid-1980s, the shores of Lake Balaton began to become saturated, and the load-bearing capacity of the lake has now bounded the boundaries. The need for sustainability has gained increasing importance, so the developments turned to the other two lakes, Lake Velence and Lake Tisza (Marton, 2013).

During the 1990 a number of national parks were established at wetland habitats (Fertö-Hanság National Park, a Balatonfelvidéki National Park, a Duna-Ipoly National Park), the national parks started to supervise areas that were valuable for them. In 1999 the Hortobágy National Park was elected among World Heritage sites and as a result the Bird Sanctuary of Lake Tisza received World Heritage protection. The Fertö-Hanság National Park had an important role in making Lake Fertö as cultural landscape a World Heritage site in 2001 so the development of eco- and natural tourism came into prominence in connection with further development of lake tourism (Mester-Polgár-Kiss, 2006). Further possibilities in the development of Lake Balaton, Lake Tisza, Lake Velence and Lake Fertö are presented by the fact that strategic Pan-European routes pass through these areas (Tóth-Dávid 2010). 


\section{The delimitation and analysis of the lake area settlements}

The analyses of the four big lakes of Hungary (Lake Balaton, Lake Fertö, Lake Tisza and Lake Velencei), similarly to other surveys, can run into difficulties. The reason is that it is utterly difficult to match geographical borders with administrative boundaries. Therefore, in order to dissolve this problem, we decided to use spatial informatics software (ArcView 9.3.1.) to define settlements whose administrative area includes even a 1 square kilometre area that belongs to the lake itself. Thus we ignored settlements situated further away from the lake. These of course can enjoy the benefits of a nearby lake but in this way we could avoid having to arbitrarily determine a distance within which settlements should be included in the surveys as this distance varies from case to case (Table 1).

During the survey 75 settlements were delimited, more than half of these had a population of between 1000 and 2000 or between 2000 and 5000. In relation to the total population the importance of these two categories is somewhat smaller, and thus the only settlement of the examined area with a population of over 50000, Sopron, can come to the limelight. All in all it can be stated that lake area settlements are mainly fragmented ones.

Table 1: Lake area settlements by population (2016)

\begin{tabular}{|c|r|r|r|r|}
\hline $\begin{array}{c}\text { Categories by } \\
\text { settlement size }\end{array}$ & $\begin{array}{c}\text { Number of } \\
\text { settlements }\end{array}$ & Distribution (\%) & $\begin{array}{c}\text { Population of } \\
\text { settlements }\end{array}$ & $\begin{array}{c}\text { Distribution } \\
(\%)\end{array}$ \\
\hline-499 & 12 & 16,9 & 3623 & 1,4 \\
\hline $500-999$ & 10 & 14,1 & 6382 & 2,5 \\
\hline $1000-1999$ & 20 & 28,2 & 28031 & 11,1 \\
\hline $2000-4999$ & 19 & 26,8 & 47104 & 18,7 \\
\hline $5000-9999$ & 4 & 5,6 & 25108 & 10,0 \\
\hline $10000-19999$ & 3 & 4,2 & 34690 & 13,8 \\
\hline $20000-49999$ & 2 & 2,8 & 45502 & 18,0 \\
\hline $50000-$ & 1 & 1,4 & 61780 & 24,5 \\
\hline Összesen & 71 & 100,0 & 252220 & 100,0 \\
\hline
\end{tabular}

Source: Hungarian Central Statistical Office, edited by the authors

\section{The current state of lake tourism}

In the following section some of the indicators - which we consider important - of lake area settlements will be examined. However, it must be noted that although the settlements themselves can be compared, it is impossible to explain the current development or processes of their socio-economic phenomena solely on the basis of tourism. Although we believe these phenomena are interconnected their background is much more complex (Table 2).

According to the most up-to-date data almost 147 thousand people lived in the 51 settlements around Lake Balaton, 66 thousand lived in the 7 settlements around Lake Fertö, 28 thousand people lived in the 12 settlements of Lake Tisza, while the 5 settlements of Lake Velence were inhabited by 23 thousand people on 1 January, 2011. These areas show a diverse picture in respect of population changes. While there has been an explicit increase in population in case of Lake Velence and Lake Fertő compared to 2000, but the population around Lake Balaton has been stagnating, and at lake Tisza there has been a decrease in population. The area of Lake Velence and Lake Ferto is characterised by significant migration, the settlements of Balaton are characterised by moderate migration, while in the area of Lake Tisza the population has been definitely migrating from the area. The Tisza Lake area is in an unfavourable position 
considering two more basic indicators, namely the unemployment rate and per capita income. The unemployment rate there is above the national average, while the specific income level is lower. The most favourable situation in respect of unemployment is observable at Lake Fertö, while in respect of income it is at Lake Velence.

Table 2: Relevant statistical data of lake area settlements

\begin{tabular}{|l|r|r|r|r|r|}
\hline Lakes & $\begin{array}{c}\text { Population } \\
\text { (1 January } \\
2016)\end{array}$ & $\begin{array}{c}\text { Population } \\
(2000=100)\end{array}$ & $\begin{array}{c}\text { migration } \\
\text { balance by } \\
1000 \text { people, } \\
(2015)\end{array}$ & $\begin{array}{c}\text { Unemploy- } \\
\text { ment rate, } \\
(2015)\end{array}$ & $\begin{array}{c}\text { Per capita } \\
\text { income, 2015 } \\
\text { (national } \\
\text { average }= \\
100)\end{array}$ \\
\hline Lake Balaton & 129881 & 100,1 & 1,2 & 5,1 & 94,6 \\
\hline Lake Fertő & 66792 & 112,6 & 10,1 & 0,9 & 86,3 \\
\hline Lake Tisza & 27739 & 91,9 & $-6,8$ & 9,3 & 72,4 \\
\hline Lake Velence & 23807 & 122,6 & 17,8 & 3,2 & 123,8 \\
\hline Country total & 9855571 & 96,6 & - & 5,9 & 100,0 \\
\hline
\end{tabular}

Source: Hungarian Central Statistical Office, edited by the authors

It is worth further considering per capita income in detail because they indicate the most important development tendencies of the areas. Of the four examined regions the most advanced area is Lake Velence and the fastest development is observable there ( $+15,2$ percentage point). Although the area of Tisza Lake is the least developed of the examined region, its development almost reached that of Lake Velence between 2000 and 2015 (+14,7 percentage point)! Lake Balaton shows a rather stagnating tendency $(+3,7$ percentage point $)$, while at Lake Ferto there has been a significant decrease reaching 17,6 percentage point! The fact that Székesfehérvár, which is one of the economic centres of Hungary, is situated nearby plays an important role in the fast improvement of Lake Velence. Also the new strategy of the Micro-regional Association of the Velencei Lake Settlements recognized, that the development of settlements around Lake Velence is almost unthinkable to the local without the quality expansion of tourism, so the development elements of the focus on strengthening tourism. It was also defined that "retrolake" can no longer be sold, so the two leading settlements of the lake - Gárdony and Velence - started to develop rapidly and demonstrably increased the number of tourists arriving mainly from Budapest. Thanks to developing accommodation and cattering facilities, enjoyable modes of transport between the settlements (development of ports), renovation and development of beaches and coastal walkway, increasing the number of events and festivals (not only in the main season), tourist attraction development, and marketing and branding (Lake Velence as a complex tourist product) resulted increasing number of visitors and incomes.

The unfavourable performance of Lake Ferto is due to the fact that the accessibility of the lake has not changed, the attraction developments financed from EU sources were finished only this year (visitor centre, reconstruction of Fertöd) and they have not made their effects felt.

The development of Lake Tisza has been facilitated by the fact that it was declared to be a priority holiday destination in 1998, then a separate tourist region was organised in its area, and a well-considered accommodation and attraction development also took place (Eco-centre in Poroszló, Robin Adventure Park in Tiszafüred). The ratio of the growth of commercial accommodation reached $70 \%$ in average. Of the different types of accommodation facilities pensions grew in the fastest rate while campsites grew only at a $25 \%$ rate. The number of holiday houses and hotels doubled since 2000 whereas the share of tourist hostels and youth 
hostels did not reach $4 \%$ combined in 2015 . The question is what regional differences prevail behind these development tendencies.

In this research the Hoover-index (also known as the Robin Hood index or Schutz index), he most frequently used regional inequality indicator in regional economics has been applied. It expresses on a $0-100 \%$ scale what percentage of one of the examined indicators (in this case the income from which income tax is calculated) should be regrouped among the settlements of certain sections so that its distribution could punctually equal with the distribution of the other indicator (in this case population) among the settlements. Since settlement groups of different sizes were examined we tried to measure the distribution changes per unit areas for the sake of comparability. Its formula is:

$$
h=\frac{\sum_{i=1}^{n}\left|x_{i}-f_{i}\right|}{2 \mathrm{n}}
$$

where $x_{i}$ and $f_{i}$ are two distribution rates (in our case the population and income share of the $i^{\text {th }}$ settlement from the total population and total income within the study area), for which the following two formula hold true: $\sum \mathrm{x}_{\mathrm{i}}=100 \%$ és $\sum \mathrm{f}_{\mathrm{i}}=100 \%$. $\mathrm{n}$ is the number of settlements in the study area.

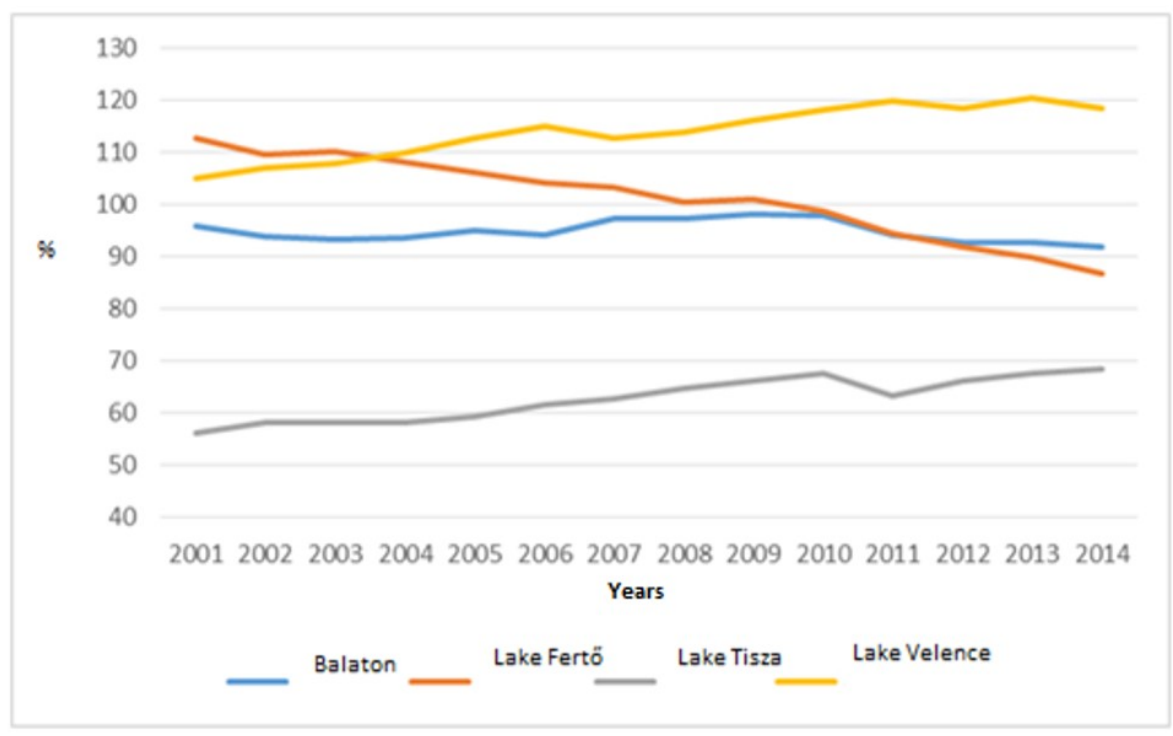

Figure 1: Per capita income of lake area population relative to Hungarian national average (percentage), 2001-2014.

Source: Hungarian Central Statistical Office, edited by the authors

The degree of the per settlement regional differences is the highest at Lake Tisza and Lake Velence and what is more the tendency is expressly positive in both cases (Table 3). On the other hand, in the case of Lake Fertö the tendency of the relatively minor differences is negative. Of the four areas Lake Balaton shows the least regional differences whose rate has not changed significantly in the past few years. The significant differences observed at Lake Velence can be explained by the rapid development of Gárdony and Velence, whereas at Lake Tisza the differences were caused by strengthening of the four large settlements in the area (Tiszafüred, Abádszalók, Kisköre, Poroszló) and the dominance of Poroszló and Tiszafüred was further 
enhanced by eco-tourism developments. At Lake Fertő the differences among the settlements are continuously diminishing due to the implementation of attraction developments.

Table 3: The Hoover-index of lake areas, 2001-2014

\begin{tabular}{|l|r|r|r|r|r|r|r|r|r|r|r|r|r|r|}
\hline Lakes & 2001 & 2002 & 2003 & 2004 & 2005 & 2006 & 2007 & 2008 & 2009 & 2010 & 2011 & 2012 & 2013 & 2014 \\
\hline $\begin{array}{l}\text { Lake } \\
\text { Balaton }\end{array}$ & 5,7 & 6,2 & 5,9 & 5,7 & 5,7 & 5,3 & 4,8 & 4,6 & 4,3 & 4,4 & 5,2 & 4,6 & 4,8 & 4,5 \\
\hline $\begin{array}{l}\text { Lake } \\
\text { Fertő }\end{array}$ & 2,0 & 1,9 & 2,0 & 1,7 & 1,6 & 1,6 & 1,5 & 1,4 & 1,3 & 1,1 & 1,2 & 1,1 & 1,1 & 1,0 \\
\hline $\begin{array}{l}\text { Lake } \\
\text { Tisza }\end{array}$ & 10,8 & 11,8 & 12,4 & 13,1 & 13,8 & 13,9 & 14,2 & 13,6 & 12,2 & 11,7 & 13,6 & 12,3 & 11,5 & 11,2 \\
\hline $\begin{array}{l}\text { Lake } \\
\text { Velence }\end{array}$ & 0,9 & 2,4 & 2,5 & 2,6 & 2,9 & 3,1 & 2,6 & 2,5 & 2,7 & 2,7 & 2,2 & 2,1 & 2,3 & 2,4 \\
\hline
\end{tabular}

Source: Hungarian Central Statistical Office, edited by the authors

Considering the turnover of commercial accommodation facilities of the examined areas, Lake Balaton rises above the others as one fifth of all guest nights were spent there (Table 4). This order of magnitude is not surprising if capacities are taken into consideration as more than one fourth of all the national accommodation facilities can be found there (Horváth 2007). Compared to 2000 the number of accommodation facilities grew only at Lake Tisza while the most significant setback occurred at Lake Fertő.

Table 4: Visitor related data of public accommodation establishments in the lake areas

\begin{tabular}{|c|c|c|c|c|}
\hline Lakes & $\begin{array}{c}\text { Guest nights, } \\
2015\end{array}$ & $\begin{array}{c}\text { Guest nights, } \\
2015 \\
(2000=100)\end{array}$ & Capacity, 2015 & $\begin{array}{c}\text { Capacity, } 2015 \\
(2000=100)\end{array}$ \\
\hline Lake Balaton & 13,2 & 86,5 & 28,7 & 133,0 \\
\hline Lake Fertő & 2,0 & 106,9 & 1,2 & 75,6 \\
\hline Lake Tisza & 0,5 & 140,0 & 1,9 & 127,6 \\
\hline Lake Velence & 0,7 & 108,9 & 1,1 & 53,0 \\
\hline All settlements & 100,0 & 133,0 & 100,0 & 118,5 \\
\hline
\end{tabular}

Source: Hungarian Central Statistical Office, edited by the authors

Between 2000 and 2015 the guest nights of commercial accommodation facilities decreased only at Lake Balaton, while the other areas experienced some growth (balatonregion.hu). The most significant increase is observable at Lake Fertö (Figure 2). The dramatic decrease at Lake Balaton can be explained by the decreasing number of foreign guests. The decrease mainly affected the camp sites $(-68 \%)$ and the holiday houses $(-56 \%)$ but compared to 2000 youth hostels also received fewer foreign guests. The other types of accommodation facilities have seen an increase, the most significant increase is connected to pensions $(+180 \%)$.

In 1990 almost half of all foreign visitors chose to stay in camp sites whose share in 2014 was only $24 \%$. Hotels increased their ratio from $45 \%$ to $68 \%$ while pensions did the same from $1 \%$ to $3 \%$. Holiday houses experienced a decrease so only $5 \%$ of the foreign guests choose them. The combined ratio of youth hostels and tourist hostels did not reach 1\% in 2009 .

The number of domestic guests changed from 139 thousand to 895 thousand during the examined period. The average six-and-a-half-time increase brought about similar positive processes for all types of accommodation facilities. Hotels have experienced an eleven-fold 
increase while pensions saw a ninefold increase and even campsites grew in this respect by almost $60 \%$.

In 2000 around $50 \%$ of domestic guests chose hotels, this number increased to $70 \%$ by 2014 , and has been constantly embracing since then thanks to the strengthening of quality orientation.

On the other hand camp sites saw a decrease from $27 \%$ to $9 \%$ while holiday houses from $15 \%$ to $8 \%$. Currently pensions have a somewhat smaller share $(6 \%)$ than youth hostels $(7 \%)$ and that of the tourist hostels' is significantly lower (1\%). It should be noted here that campers' expectations are getting higher and higher. Camping has now become a lifestyle and its guests are not characterized by low solvency. The development of our great lakes in this field is justified, and must consider the expectations of potential guests.

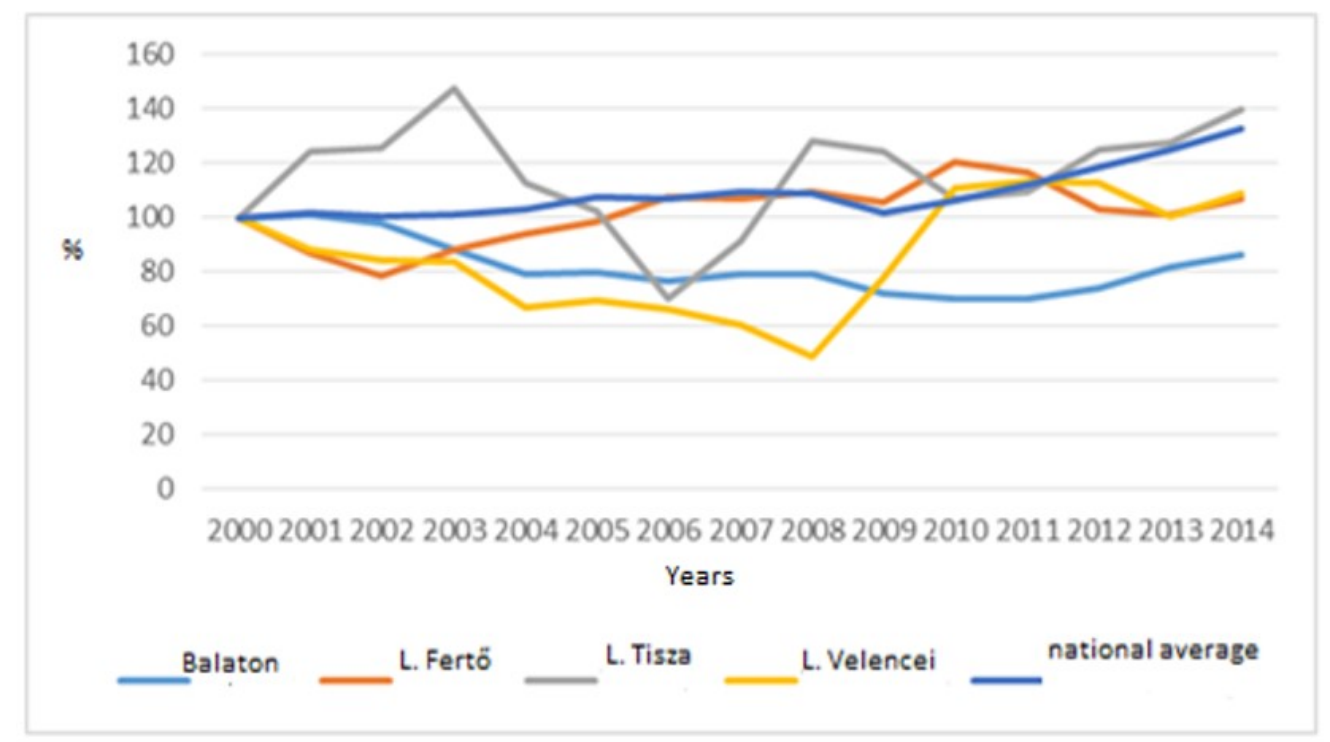

Figure 2: Number of guest nights at public accommodation establishments Source: Hungarian Central Statistical Office, edited by the authors

In respect of the category currently called "other" (until 2009 it was referred to as "private") the dominance of Lake Balaton is even more significant. Four out of 10 guest nights are spent there and half of the accommodation capacity can be found there. Compared to 2000 the number of accommodation capacity decreased only in this area and at Lake Velence while at the two other lakes there has been a significant increase (Table 5).

The number of commercial accommodation capacity of the Balaton Region stood at 76 thousand in 2015, which made it number one of the examined regions in the whole examined period. The capacity increased by almost $20 \%$ in the region between 2000 and 2015 . Only the above mentioned campsites show a decrease, while other types experienced a significant growth. Of the tourist products camp-site tourism lost the most as in 1990 more than $70 \%$ of the capacity was in camp sites, this decreased to $32 \%$ by 2009 . 
Table 5: Visitor related data of other (private) accommodation establishments in the lake areas

\begin{tabular}{|l|c|c|c|c|}
\hline Lakes & $\begin{array}{c}\text { Guest nights, } \\
\mathbf{2 0 1 5}\end{array}$ & $\begin{array}{c}\text { Guest nights, } \\
\mathbf{2 0 1 0} \\
\mathbf{( 2 0 0 0 = 1 0 0 )}\end{array}$ & $\begin{array}{c}\text { Capacity, } \\
\mathbf{2 0 1 5}\end{array}$ & $\begin{array}{c}\text { Capacity, } \\
\mathbf{2 0 1 5} \\
\mathbf{( 2 0 0 0}=\mathbf{1 0 0})\end{array}$ \\
\hline Lake Balaton & 28,4 & 67,4 & 44,0 & 66,7 \\
\hline Lake Ferto" & 1,1 & 193,4 & 0,5 & 166,7 \\
\hline Lake Tisza & 1,2 & 253,0 & 2,1 & 171,1 \\
\hline Lake Velence & 0,3 & 100,5 & 1,2 & 79,7 \\
\hline All settlements & 100,0 & 115,8 & 100,0 & 97,9 \\
\hline
\end{tabular}

Source: Hungarian Central Statistical Office, edited by the authors

Between 2000 and 2015 the number of guest nights at other accommodation establishments decreased at Lake Balaton and at Lake Velence, while there has been an increase in the other two regions. The most significant increase is at Lake Tisza (Table 4).

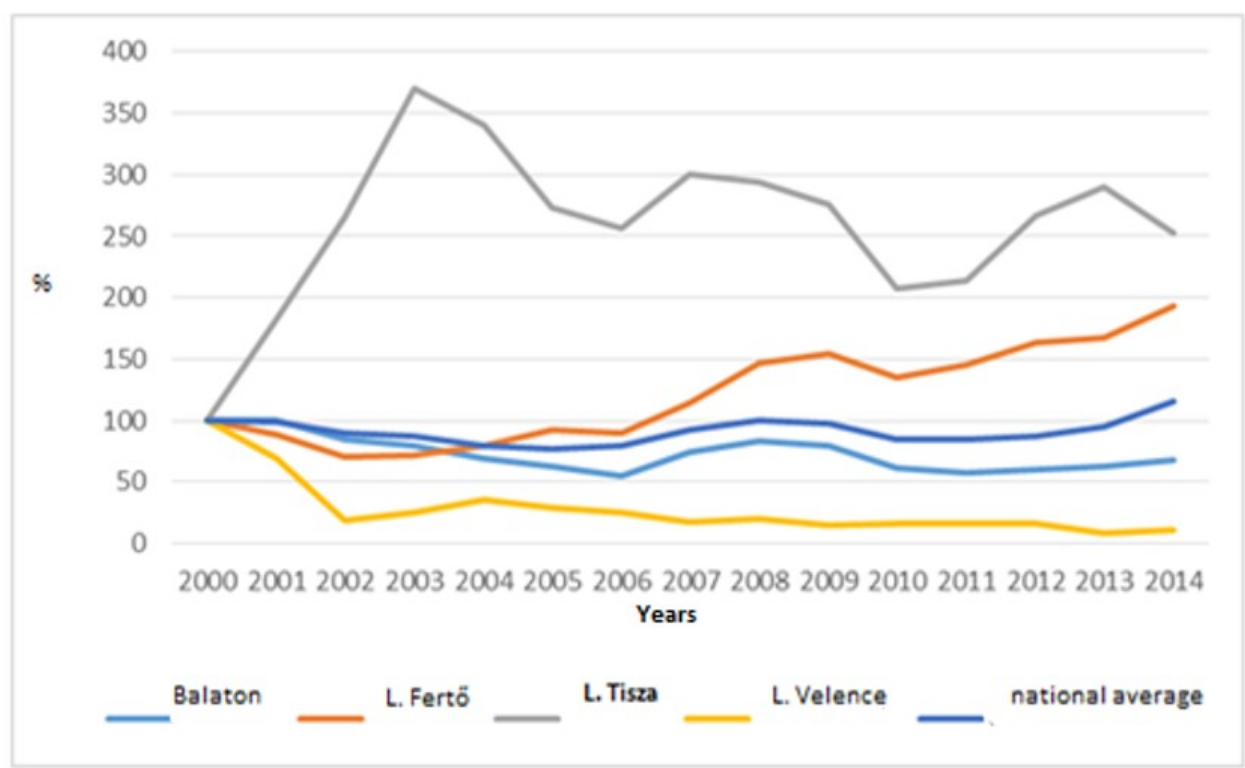

Figure 3: Number of guest nights at other (private) accommodation establishments (percentage) $\mathbf{2 0 0 0}=\mathbf{1 0 0}$.

Source: Hungarian Central Statistical Office, edited by the authors

At Lake Tisza there were 21 thousand visitors in 2000 and it remained similar in 2014. The intrinsic structure of the $2 \%$ increase was similar to the domestic ones: Campsites suffered significant - almost 20\% - losses, nevertheless hotels had an even worse period as their losses reached almost $25 \%$. The other types show significant increases.

In 2014 almost half of the foreign guests chose campsites followed by hotels. There was a significant increase in connection with the holiday homes as a result of which their ratio currently stands at $13 \%$. The share of other type of accommodation establishments is negligible (Table 6).

The domestic guest nights in the region grew from 123 thousand to 196 thousand, which represent an almost $60 \%$ improvement. The greatest, more than double, increase can be observed at hotels, but pensions and holiday homes had a significant increase as well. In 2014 the visitors spent one third of all guest nights at hotels, in 1990 this rate did not even reach $10 \%$. 
The rate of pensions and holiday homes is similar (24-20\%) respectively. In 1990 campsites were in the fourth place with $80 \%$, currently their rate does not reach $20 \%$.

\section{The Balaton Research}

\section{Tourism of Lake Balaton}

The Balaton Law originally listed 164 settlements in the Lake Balaton Resort area. Later, with new connections, the number of settlements belonging to the district increased to 180 . With acceptance of Tourism Development Government Decree in December 2016 the Balaton tourism area now covers 174 settlements. The legislation has slightly altered the scope of the tourist region of Lake Balaton, since in the future Veszprém and Sümeg belong to this area as well.

Balaton is one of the most important natural resources of our country. The Lake and its surroundings are iconic destinations of Hungarian tourism and do play important role. The area's recreational history dates back to the 19th century (Rátz - Michalkó, 2007). The development of the region and its aspiration to independence were closely linked to the economic development and strengthening of tourism. Bathing at Lake Balaton was first strengthened on the northern shore, the southern shore was only slightly delayed. The image of the region has been strongly formed by the water mass tourism for decades, but in the last period besides this type of tourism, the area offers experiences also for those who interested in spas, wine, natural parks active or cultural- especially festival tourism. There is an increasing number of non-measurable and non-conventional tourists as well (VFR, second home owners or onedayvisitors for example), but the number of summer waterside tourists is still the highest.

According to the data of Hungarian Central Statistical Office domestic demand is the highest and realized mainly during the summer season (3rd quarter of the year). The second - and increasing - most popular season is spring, thanks to the long weekends of Easter, Pentecost, $1^{\text {st }}$ of May and spring school holiday. In autumn the excursion and wine tourist visit the area. Focusing on the data of international demand the German and Austrian visitors made the largest foreign guest share (40\% together) in 2016 followed by the Check, Polish and Slovakian guests. Although its share is decreasing, Russian market is still very important in particular that Russian guests typically do not arrive in the high season and their willingness to spend is fairly high.

The strategy of the four-year Balaton is currently being developed. With proper development grants and effective communication the wild variety of tourism attractions and resources can reach the goal.

The tourism businesses of Lake Balaton concentrated in Siófok and Balatonfüred, in line with the tourist traffic data, but the number of business per inhabitant in Hévíz and Zalakaros the highest. Examining the number of businesses, we can state that the highest is the number of catering businesses (mainly restaurants) followed by accommodation (mainly hotels), than by spa and recreational and entertainment and leisure services. More than $60 \%$ of the total touristic revenues of the Balaton tourism region came from the income of five cities: Siófok, Balatonfüred, Hévíz, Zalakaros and Keszthely.

\section{Results of the questionnaire survey}

The questionnaire research made by the Academy of Tourism of the Budapest Business School University of Applied Sciences took place at Lake Balaton between 2nd of July and the 12th of 
July 2015. The research was made by 19 third-year student and they observed 45 settlements near the lake. The focuspoints of the research were Siófok, Balatonfüred, Révfülöp, Keszthely and Fonyód. With the help of tablets the students filled out 30 questionnaires per day so by the end of the research they managed to collect more than 6000 surveys. The survey consisted of 20 simple and multiple choice questions. Besides of the questions focusing on the target groups they were also interested in the travelling habits of the visitors, which attraction and transportation they prefer, how they rate the effects of tourism and the image of Lake Balaton. Foreign tourists were interviewed in English and German.

The local tourists were given a 19-item questionnaire, which mainly focused on how satisfied the locals felt in the particular city. Therefore, the majority of the questions were based on the landscape, socializing, job opportunities and tourism statistics, which we evaluated on a scale from 1 to 5. The enquiries also wanted to find out which attractions the locals are most proud of in their surroundings and what programs they would recommend for visiting tourists.

On the north coast of Balaton, most of the domestic respondents who came from Budapest arrived by car and spent 3-4 days in the particular area, either in the summer cottage of their relatives or friends or in apartments. The respondents went to rest and bathe and stayed mainly in Balatonfüred or near Badacsony. Young couples preferred to visit Balatonfüred, Keszthely or Tihany, pensioners liked Zalakaros and Badacsony, and families visited adventure parks and Veszprém zoo during their stay at Lake Balaton. The respondents agreed that they will visit the Major farm in Salföld and the Tapolca Lake Cave while staying on the north coast. Regarding the evaluating questions, accommodations were rated 4-5 stars, the quality of roads 3-4, service of beaches 4, and quality-price ratio as 3-4 stars. According to them, services and products did not get more expensive even though it's Lake Balaton.

The most pleasant experience of the respondents was mostly the beach and the city of Balatonfüred, and the sight of the Balaton itself. Everyone would recommend Balaton to their friends.

About $80 \%$ of the respondents did not use a Széchenyi Recreation Card (SZÉP card) during their stay and about $50 \%$ of these never even had it. It was an interesting and unexpected result, because the number of service providers accepting SZÉP card and the revenue generated by it shows a continuous increase during the last years, resulting 257 units and revenue of more than 5 billion HUF in the Lake Balaton region in 2016 (Sulyok-Lörinczi, 2016). They spent an average of 20-30.000 HUF on accommodation. This is considered rather cheap (those who didn't stay in a cottage were accommodated in an apartment). During the 3-4 days, they spent 15-20.000 HUF on different services per person. The number of passengers was usually around 2-4 persons.

The locals had a similar opinion regarding the evaluations as tourists, but they weren't satisfied with the offered accommodations and they felt like quality accommodations were missing.

The locals all rated the beautiful Balaton environment a 5, and they also agreed, that the landscape of Balaton is also great compared to foreign countries. They shared the opinion that if accommodations were to stay open outside of season, more tourists would arrive, and this would provide locals with more job opportunities. The most local respondents would recommend Balatonfüred, Tihany, the Káli Basin, Salföld and Tapolca Lake Cave to tourists. Locals were most proud of the orderly parks in their area. 
According to the employees of the local tourist information office "Tourinform", it would be worth to organize more active programs in the city and advertise the given opportunities more.

Foreign tourists were really satisfied with the prices, services and helpfulness of the locals at Lake Balaton. They also liked the variety of programs and out of the sights near Balaton they pointed out Tihany abbey and Balatonfüred. The respondent foreign tourists spent 1 week on average on the lake shore.

On the south shore of Balaton, the domestic respondents arrived from Budapest and Somogy county by car and spent about 4-5 days in the area in the cottage of relatives or friends. The other part of the respondents stayed in camping sites, summer cottages or apartments. Among the youth, Siófok and Zamárdi were the most popular holiday destinations, and foreign tourists also preferred these areas. It is worth mentioning, that the popular music festivals of recent years as B.my.lake or Balaton Sound have directed the attention to this settlement. In the TOP 25 Hungarian settlements (by the number of guest nights) Zamárdi was the $18^{\text {th }}$ and has moved 8 places with a $73 \%$ increase in guest nights over the last decade (Table 6)

Families liked Balatonlelle and Fonyód, and pensioners mentioned Hévíz as their favourite place to stay. Many young adults and foreigners mainly came because of the Balaton Sound festival in Zamárdi, whereas families liked the Zamárdi adventure park the best. The older age group visited Festetics castle.

Table 6: Sequence of the big lakes settlements in TOP25 by the guest nights

\begin{tabular}{|c|r|r|r|r|r|r|}
\hline \multirow{2}{*}{$\begin{array}{c}\text { sequence in } \\
2016\end{array}$} & \multirow{2}{*}{ settlement } & \multirow{2}{*}{$\begin{array}{c}\text { Guest nights } \\
2016\end{array}$} & \multicolumn{2}{|c|}{$\begin{array}{c}\text { Change of guest nights } \\
(\%)\end{array}$} & \multicolumn{2}{c|}{ Change of sequence } \\
\cline { 4 - 7 } & & & $2000=100$ & $2008=100$ & $2000=100$ & $2008=100$ \\
\hline 1. & Hévíz & 1056052 & $+8,6$ & $+16,1$ & 0 & 0 \\
\hline 3. & Siófok & 756281 & $+6,0$ & $+13,3$ & 0 & 0 \\
\hline 5. & Balatonfüred & 617567 & $+3,6$ & $+6,8$ & 0 & -1 \\
\hline 6. & Zalakaros & 500309 & $+5,1$ & $+32,4$ & 0 & +1 \\
\hline 18. & Zamárdi & 197315 & $+7,8$ & $+173,0$ & +1 & +8 \\
\hline 21 & Velence & 190052 & $+114,6$ & $\% 568,5$ & +9 & +8 \\
\hline
\end{tabular}

Source: Hungarian Central Statistical Office, edited by the authors

\section{The local residents' opinion about the tourism of Balaton}

In the course of research about local residents' opinion can be related (7. table), that regarding the first variables of the survey, in the smallest settlement examined by us (in Tihany) the best results were attained. The most frequent answers were: nice and fresh environment, fresh air, calm living conditions, clear and ordered settlement, public safety, services which can be reached easily, solidary local community. The statements belonging to the second part, which had a categorisation from 1 until 5, the two most popular settlements are Hévíz (high season tourist traffic, job opportunities) and Siófok (public transport, real estate prices, study and professional development opportunities, job opportunities), which the tourists mentioned opposite other cities. 
Table 7: Satisfaction index

\begin{tabular}{|c|c|c|c|c|c|c|c|c|}
\hline $\begin{array}{l}\text { evaluation } \\
\text { aspects }\end{array}$ & Balatonfüred & Hévíz & Keszthely & Siófok & Tihany & $\begin{array}{l}3000 \\
>\text { per } \\
\text { capita }\end{array}$ & $\begin{array}{c}1000- \\
3000 \\
\text { per } \\
\text { capita }\end{array}$ & $\begin{array}{l}3000< \\
\text { per } \\
\text { capita }\end{array}$ \\
\hline $\begin{array}{l}\text { beautiful } \\
\text { natural } \\
\text { environment }\end{array}$ & 4,85 & 4,66 & 4,57 & 4,64 & 4,94 & 4,55 & 4,64 & 4,61 \\
\hline $\begin{array}{l}\text { clean air, } \\
\text { healthy } \\
\text { environment }\end{array}$ & 4,79 & 4,56 & 4,32 & 4,58 & 4,97 & 4,44 & 4,58 & 4,67 \\
\hline $\begin{array}{l}\text { calm living } \\
\text { conditions }\end{array}$ & 4,66 & 4,06 & 4,22 & 3,92 & 4,9 & 4,36 & 4,29 & 4,64 \\
\hline $\begin{array}{l}\text { cleanly, } \\
\text { organized } \\
\text { settlement }\end{array}$ & 4,73 & 4,28 & 4,02 & 4,17 & 4,72 & 4,02 & 4,29 & 4,27 \\
\hline $\begin{array}{l}\text { high season } \\
\text { tourist traffic }\end{array}$ & 4,25 & 4,69 & 4 & 4,47 & 4,09 & 4,13 & 4,02 & 4,18 \\
\hline public safety & 4,18 & 3,66 & 3,25 & 3,95 & 4,69 & 3,6 & 3,83 & 4,15 \\
\hline $\begin{array}{l}\text { easily } \\
\text { accessible } \\
\text { services }\end{array}$ & 3,48 & 4,03 & 3,73 & 4,08 & 2,81 & 3,78 & 3,4 & 2,67 \\
\hline $\begin{array}{l}\text { cohesive } \\
\text { local } \\
\text { community }\end{array}$ & 2,95 & 2,97 & 3,1 & 3,33 & 3,47 & 3,67 & 3,32 & 3,68 \\
\hline $\begin{array}{l}\text { public } \\
\text { transport }\end{array}$ & 3,39 & 3,09 & 2,73 & 3,58 & 3,59 & 3,24 & 2,98 & 2,97 \\
\hline $\begin{array}{l}\text { road } \\
\text { conditions }\end{array}$ & 3,42 & 2,81 & 2,47 & 3,27 & 4 & 2,97 & 3,1 & 3,06 \\
\hline $\begin{array}{l}\text { property } \\
\text { prices }\end{array}$ & 2,67 & 2,75 & 2,98 & 3,13 & 2,79 & 3,26 & 3,18 & 3,08 \\
\hline $\begin{array}{l}\text { study } \\
\text { opportunities }\end{array}$ & 2,92 & 3,38 & 3,28 & 3,28 & 2,38 & 3,43 & 2,49 & 2,24 \\
\hline $\begin{array}{l}\text { job } \\
\text { opportunities }\end{array}$ & 2,72 & 3,22 & 2,8 & 3,02 & 2,65 & 2,6 & 2,61 & 2,77 \\
\hline $\begin{array}{l}\text { national } \\
\text { average }\end{array}$ & 3,77 & 3,71 & 3,5 & 3,8 & 3,85 & 3,69 & 3,59 & 3,61 \\
\hline
\end{tabular}

Source: Budapest Business School

Regarding the local residents' residential time mostly, the persons living for a longer time in the region formed a judgement on the effects of the tourism more negatively, the shorter time inhabitants thought the tourism of more positive one, but they were aware of the benefits of the tourism and its disadvantages independently of the time spent in the settlement. It is also a manifest from the analysis that the development of the tourism has been favoured the best by the settlements' new residents. The elder residents were more tolerant opposite the foreign tourists and the harmful environmental effects caused by the tourism were not considered alarming ones. The gender of the respondents influenced their opinions formed about the tourism as well. The women opposed the tourism generally stronger, because of its negative effects, especially because of the increase of the traffic, the noise pollution and delinquency. 


\section{Summary}

The waterside tourism is still the most sought tourism product in Hungary as well, but lake destinations should focus on the main global trends related to world tourism issues. It means, that besides the traditional coast activities characterized by the $3 \mathrm{~S}$ (see=water, sound and sun) has to be completed with other offered activities.

Developing active tourism facilities - summer and winter sports, cycling, fishing, horse riding - is important not only for targeting new consumer groups, but also to give an opportunity for areas beyond the water. It is particularly important to win young and people - especially with high solvency - among the tourism products of active tourism the summer- and the winter water sports could be included in the supply elements of the lake tourism with a bigger emphasis, to this big water ski, wakeboard, kitesurf and the today very popular flyboard tracks would be necessary.

For the foreign guests and the forming of qualitative tourism the development of the star grade system of the accommodations would be necessary besides product development such as gastro- and wine tourism (wine festivals, fish baking, pig cuts etc.), health tourism (the vinotherapy can be linked to wine tourism), or cultural tourism.

In the opinion of the respondents the qualitative local products with an extraordinary flavour receive a very small attention. It would be possible to hold a market monthly for local products and producers; here it would be possible to outline the local excellences. The importance of local products are the following: contributes to the sustainability of the environment, making working and earning supplement for the residents, developing local economy, makes shorter food chain and healthier foods and - as an important social impact - in case of more service providers, producers, craftsmen and hosts have a community-building effect as well. The milieu of local producer markets is also an experience for tourists.

Regarding the government decision the national parks have to continue on their areas to build visitor and show centres (in Fenékpuszta, at Kis-Balaton a visitor centre is being built in 2017). The development of the eco-tourism could be a special task on the area of the lake tourism. The National Castle Program launched in the framework of the Széchenyi 2020, is also a new opportunity to the lake destinations (mainly Balaton Region). The first stage of the program affects Sümeg Castle and Bishop's Palace, the second the Kinizsi Castle in Nagyvázsony and in the third stage gives the opportunity for developing three castles in Veszprém County (Döbrönte, Gyulakeszi and Szigliget). The program also offers the opportunity to develop modern museum pedagogical methods, so while preserving the monuments, the advantage of enriching the offer with new experience programs for all generation groups and individuals can be reached.

Change the marketing communication of lake tourism would be necessary as well. Using web2.0 communication interfaces - such as Facebook, YouTube, Twitter, Instagram or Pinterest) is indispensable today.

With the usage of the EU and government resources for tourism, the creation of an independent image of Balaton, Lake Tisza, Lake Fertő and Lake Velence would be important. 


\section{References}

1. Central Statistical Office (2016): Tourism economy in Balaton Region. www.ksh.hu/docs/hun/xftp/idoszaki/regiok/veszpremturizmusgazd.pdf

2. Cooper C. etal. (2008): Tourism: Principles and Practice. 4th Edition. Pearson Education Limited: England.

3. Dávid L. - Tóth G. - Kelemen N. - Kincses Á. (2007): A vidéki turizmus szerepe az Észak-Magyarország Régióban, különös tekintettel a vidékfejlesztésre a 2007-2013. évi agrár- és vidékpolitika tükrében. Gazdálkodás, 51. évfolyam 4. szám, pp. 38-57.

4. Horváth Z. (2007). A turizmus szerepe a foglalkoztatáspolitikában, a Balaton régióban. Turizmus Bulletin 11. 4. 20-29.

5. Káposzta, J.-Nagy, A.-Nagy, H. (2013): Tourism infrastructure index and the distribution of development funds in statistical regions of Hungary Agrarnyi Vestnik Urala / Agrarian Bulletin of the Urals 2013:(12) pp. 80-83. (2013)

6. Káposzta, J.-Nagy, A.-Nagy, H. (2014): Efficiency of Hungarian regions in using the development funds for touristic purposes. Regionalnaja Ekonomika: Jug Rossii / Regional Economy: The South of Russia 4:(6)pp. 33-39. (2014)

7. Marton I. (2013): A Balaton régió fejlődése. A regionális gondolkodás és a turizmus fejlődésének összefüggései a Balaton térségében. Acta Scientiarum Socialium 39 pp. 161-179.

8. Mester T. - Polgár J. - Kiss K. (2006): A Balaton turizmusának az alakulása a statisztikák tükrében. Turizmus Bulletin X. különszám. 63-69.

9. Mill R. C. -Morisson A. M. (1992): The Tourism System. An Introductory Text. 2nd Edition. Prentice-Hall International Editions.

10. Nagy, H.- Káposzta, J. (2010): Social and regional aspects of the structural and Cohesion Funds in the new EU member states between 2007-2013. In: Peter Bielik (szerk.): Economics, Social Policy and Citizenship in the European Union - Evidence of V4 Countries and Perspectives for Ukraine. 258 p. Nitra: Slovak University of Agriculture, Faculty of European Studies and Regional Development, 2010. pp. 148167. ISBN: 978-80-552-0448-2

11. Rátz T. - Michalkó G. (2007): A Balaton turisztikai miliője. Turizmus Bulletin 11. 4. 13-19.

12. Rehák (2011): Turizmuspolitika Magyarországon. PhD-disszertáció. Debrecen.

13. Remenyik - Tóth - Molnár (2013): A tóturizmus helyzete és fejlesztési lehetőségei Magyarországon. Agora. 2013(10) pp. 90-105.

14. Sulyok M.J. - Lörincz K. (2016): Building the future based on the past - Tourism around the Lake Balaton. Pannon Management Review 6(1-2) pp. 9-18.

15. Tóth G. - Dávid L. (2010). Tourism and Accessibility: An Integrated Approach Applied Geography 30: (4) 666-677.

16. www.ksh.hu

17. www.balatonregion.hu/turizmus 